\title{
EFFECTS OF ORGANIC, CHEMICAL AND INTEGRATED NUTRITION SYSTEMS ON MORPHO-PHYSIOLOGICAL TRAITS OF OREGANO (Origanum vulgare L.)
}

\author{
Shirin NIKOU ${ }^{1}$, Bahram MIRSHEKARI ${ }^{2 *}$, Mahmoud POORYOUSEF MIANDOAB ${ }^{3}$, Varahram \\ RASHIDI $^{1}$, Abdollah HASSANZADEH GHORTTAPEH ${ }^{4}$ \\ ${ }^{1}$ Department of Agronomy and Plant Breeding, Tabriz Branch, Islamic Azad University Tabriz, IRAN \\ ${ }^{2}$ Associate Professor, Department of Agronomy and Plant Breeding, Tabriz Branch, Islamic Azad \\ University Tabriz, IRAN \\ ${ }^{3}$ Associate Professor, Department of Agronomy and Agro-ecology, Urmia Branch, Islamic Azad \\ University, Urmia, IRAN \\ ${ }^{4}$ Horticulture Crop Research Department, West Azerbaijan Agricultural and Natural Resources Research \\ and Education Center, AREEO, Urmia, IRAN \\ *Corresponding author: Mirshekari@iaut.ac.ir
}

Received: 23.11.2018

\begin{abstract}
In order to evaluate the effects of organic, chemical and integrated nutrition systems on morpho-physiological traits of oregano (Origanum vulgare L.), an experiment was carried out at the experimental farm of the Agricultural and Natural Resources Research Center, Urmia, Iran, during 2016-2017 growing season. The experimental design was a completely randomized block design with three replications. The experimental treatments included NPK, two organic (vermicompost and biochar), two biological (nitroxin and bio super phosphate) fertilizers and their all twin combinations and control (non-fertilized). Our results showed that the application of organic fertilizers caused a significant increase in yield and essential oil content in oregano. On the other hand, integrated nutrition treatments had the most effect on increasing the traits in compared with the individual treatments. The highest essential oil yield was obtained from Nitroxin treatment $\left(871.27 \mathrm{~kg} \mathrm{ha}^{-1}\right)$ in the second year. Whereas, the lowest value of essential oil yield was found in control (non-fertilized) $(25.92$ $\mathrm{kg} \mathrm{ha}^{-1}$ ) in the first year. The present study clearly indicated that chemical fertilizers could be replaced by biofertilizers resulted in similar oil yield.
\end{abstract}

Keywords: Biochar, biological fertilizers, essential oil yield

\section{INTRODUCTION}

Due to the considerable effects of plants medication and their healthcare characteristics, in worldwide the use of medicinal plants and natural antioxidants are increasing continuously (Raut and Karuppayil, 2014). The important thing in producing these plants is to increase their biomass production without the use of chemical fertilizers. So that the use of microbial species in collaboration with medicinal plants will be effective in improving their quality and performance (Karthikeyan et al., 2008). Oregano (Origanum vulgare L.) belongs to the Lamiaceae family, which is indigenous to the Mediterranean region. This plant plays the main role among culinary herbs in world trade. Traditionally, leaves and flowers of oregano are used in Lithuania mostly for their beneficial properties to cure cough and sore throats and relieve digestive complaints (Radušienè et al., 2008). Also, oregano is popular culinary herbal crops that generally used in the agriculture, pharmaceutical and food industry (Aligianis et al., 2001).

Fertile soil is the basic resource for higher crop production, which supplies all the essential nutrients to the crop. So maintenance of soil fertility can be a pre-requisite for long-term sustainable crop production (Schroth and Sinclair, 2003). Rao (2001) believed that long-term use of chemical fertilizers depleting soil organic matter, causing soil degradation and environmental pollution problems. So to avoid the risk of these negative effects of them, it is necessary to use organic or biological fertilizers which provide plant nutrients and also increase the long-term sustainability of agroecosystems (Mehnaz and Lazarovits, 2006). There is a strong relation between soil organic matter content and fertility, widely and universally accepted (Melero et al., 2007). 
Organic fertilizers are carbon-based compounds that increase the productivity and improve quality of plants (Leu, 2007). They have different benefits like low priced and eco-friendly inputs that have a great prospect of supplying nutrients which can reduce over-dependence on chemical fertilizer (Bajeli et al., 2016).

Soil fertilization management and the addition of biochar to soil can be used as one of the appropriate solutions. It is sustainable coal, has high nutrient and carbon-rich (Atkinson et al., 2010). The results of various studies showed that the use of biochar increases and improves the efficiency of nitrogen fertilizer in different soils and finally, the higher nitrogen uptake in the plant (Ding et al., 2010). Vermicompost is a kind of organic fertilizer which has a high porosity and a high ability for absorption and protection of mineral nutrients (Marinari et al., 2000). Sinha et al. (2010) Mentioned that vermicompost is enriched with several beneficial soil microbes and also contains many essential plant nutrients like N, P and K. Also, soil from the plot in which vermicompost was added, showed the highest number of bacterial colonies per gram of soil. Marinari et al. (2000) reported that total porosities were $24 \%$ higher in soil treated with vermicompost compared to soil without fertilizer. The major problem with organic fertilizers is that the nutrients supplied through them are not enough to sustain the productivity of high yielding food and other crops. Therefore, the best offer is to manage the crop with a wise combination of the organic and inorganic source of plant nutrients, putting less emphasis on expensive synthetic inorganic fertilizer (Patra et al., 2000).

One of the biological ways to increase production in agriculture, is the application of useful soil microorganisms which can increase plant growth and yield in different ways, such as plant growth promoting rhizobacteria (PGPR) (Vessey, 2003). These bacteria are known as «yield promoting bacteria» because they improve increasingly growth and development of plants (Sturz and Christie, 2003). Among the PGPBs, Pseudomonas putida and Azotobacter chroococcum are the greatest common species, founding in the soil, that fix phosphorus and nitrogen, respectively (Seilsepour et al., 2002; Vessey, 2003). In last few decades a large array of bacteria including species of Azospirillum, Azotobacter, Pseudomonas, Enterobacter, Arthrobacter, Burkholderia and Bacillus have reported enhancing plant growth (Maurya et al., 2014; Meena et al., 2013; Meena et al., 2014).

Considering the importance of Origanum vulgare L. and the positive effects of growth stimulator rhizospheric bacteria, the objective of this research, was to investigate the effect of chemical, organic and biological fertilizers and year on some quantitative and qualitative traits of oregano.

\section{MATERIALS AND METHODS}

\section{Field study}

The experiment was conducted at the experimental farm of the Agricultural and Natural Resources Research Center, West Azerbaijan, Urmia, Iran. That is located at latitude $37^{\circ} 44^{\prime} \mathrm{N}$, longitude $45^{\circ} 02^{\prime} \mathrm{E}$ and at an altitude of $1352 \mathrm{~m}$ above mean sea level during two successive seasons of 2016-2017 and 2017-2018. The climate is semi-arid with a mean annual precipitation of $390 \mathrm{~mm}$ and an average temperature of $11.3^{\circ} \mathrm{C}$. The soil characteristics from the experimental field, biochar and vermicompost fertilizers are given in Table 1.

Table 1. Physical and chemical properties of the soil, biochar and vermicompost.

\begin{tabular}{|c|c|c|c|c|c|c|c|}
\hline & Texture & $\begin{array}{c}\text { Total N } \\
(\%)\end{array}$ & $\begin{array}{l}\text { Phosphorus } \\
\text { (ppm) }\end{array}$ & $\begin{array}{l}\text { Potassium } \\
\text { (ppm) }\end{array}$ & $\begin{array}{c}\mathrm{EC} \\
\left(\mathrm{dS} \mathrm{m}^{-1}\right)\end{array}$ & $\begin{array}{l}\mathrm{OC} \\
(\%)\end{array}$ & $\mathbf{p H}$ \\
\hline Biochar & - & 1.12 & 2790 & 26600 & 1.04 & 39.8 & 8.60 \\
\hline Vermicompost & - & 1.27 & 12500 & 20600 & 2.68 & 20.38 & 8.01 \\
\hline Field soil & Silt-clay-loam & 0.13 & 2.6 & 265 & 0.78 & 1.32 & 7.62 \\
\hline
\end{tabular}

The experimental design was a complete randomized block design with three replications. The experimental treatments were NPK $(20 ; 20 ; 20)$, two organic fertilizers (biochar and vermicompost) and two biological fertilizers (nitroxin and bio super phosphate), their all twin combinations and control (non-fertilized). Biochar and vermicompost were prepared at the rates of 10 and $7 \mathrm{t} \mathrm{ha}^{-}$ ${ }^{1}$, respectively. The NPK fertilizer, in the amount of $15 \mathrm{~kg}$ $\mathrm{ha}^{-1}$, was added to the plots one day before planting and mixed with soil. Nitroxin biological fertilizer was applied according to the manufacturers recommended in second and third irrigation ( 5 liter ha $\mathrm{h}^{-1}$ with irrigation water) and bio super phosphate in second irrigation (3 liter ha ${ }^{-1}$ with irrigation water) after transfer of transplants. Nitroxin biofertilizers consists of the most effective species of nitrogen stabilizing bacteria including the genus
Azotobacter, Azospirillum and phosphate solubilizing bacteria including the genus Pseudomonas. Effective agents was: $10^{8}$ culture forming unit $(\mathrm{CFU})=10^{8}$ Azospirillum, Azotobacter, Pseudomonas. Bio Super Phosphate biofertilizer is made of group of PhosphateSolubilizing bacteria (PSB) of various genera of Pseudomonas and Bacillus. Colony Forming Unit (CFU) was $10^{8} \mathrm{ml}^{-1}$. Biofertilizers were prepared from the Mehr Asia Biotechnology Company in Iran.

In order to prepare biochar fertilizer, the grape pruning waste and stubble were placed in an oven at $250^{\circ} \mathrm{C}$ for 4 hours under anaerobic conditions. Then the coal was crushed, passed through the sieve in order to have the same particles in the soil (Lehmann, 2007; Kim et al., 2012). 
The seed of oregano were sown in small pots in on March 6, 2016 (9 $\mathrm{cm}$ height and $7 \mathrm{~cm}$ diameter) under greenhouse conditions. Then ninety-days old seedling were transferred outdoor on June $4^{\text {th }}$ and they were hand sown in $1.60 \times 3 \mathrm{~m}$ plots with $40 \mathrm{~cm}$ inter-row and $25 \mathrm{~cm}$ intra-row spacing in four rows. The first irrigation was implemented immediately after transplanting and two irrigation stages were also done with 3 and 7 day intervals, then irrigation continued every 10 days. During growing season, hand weeding was conducted at five times.

\section{Morphological measurement}

Plant height was measured from the soil surface to the tip of the tallest flowering stem at full flowering stage. For each treatment, measurement of fresh and dry matter weights were evaluated by harvest of six randomly selected plants from the center rows of each plot. Plants were harvested at a height of $5 \mathrm{~cm}$ above the soil surface and after that plants were dried in an oven at $65^{\circ} \mathrm{C}$ for 48 $\mathrm{h}$ and weighted (dry matter weight). The proportion of leaves, stems and flower were separately determined by weighting of these segments with a digital balance. The fresh and dry herb yield $\left(\mathrm{kg} \mathrm{ha}^{-1}\right)$ was determined by harvesting a $1.1 \mathrm{~m}^{2}$ area from each plot. The collected plants were dried in the shade until it reached a constant weight and were weighted by a digital balance.

\section{Essential oil content and yield}

Fresh plants were cut at full flowering stage. From each plot, the sample of the herb was shade dried for two weeks. After grinding the samples of leaf and flowers, 50 $\mathrm{g}$ of sample weighted and suspended in $750 \mathrm{~mL}$ distilled water. Ground mass was subjected to hydro-distillation using Clevenger's apparatus (Clevenger, 1928). After $4 \mathrm{~h}$, the essential oils were collected and dehydrated with sodium sulphate $\left(\mathrm{Na}_{2} \mathrm{SO}_{4}\right)$ using the Guenther (1961) method. Then essential oil yield and percentage were measured by using following formula:

$$
\operatorname{EOY}\left(\mathrm{kg} \mathrm{ha}^{-1}\right)=\mathrm{EO}(\%) \times \mathrm{DW}\left(\mathrm{kg} \mathrm{ha}^{-1}\right)
$$

EOY is essential oil yield, EO and DW are essential oil and dry herb yield, respectively.

\section{Nutrient concentration in oregano leaves}

For nutrients analysis in the oregano herb, the plant samples (leaves) were dried separately in an oven at $65^{\circ} \mathrm{C}$ for 48 hours and then the dried samples were powdered. Leaf nitrogen percentage was determined by the cadmium reduction method, available phosphorus was determined using the method described by Olsen and Sommers (1982). Also, potassium concentration of plant samples was measured with flame photometer.

\section{Statistical analysis}

Data were statically processed by analysis of variance (ANOVA) with using of SAS (Version 9.1) software, followed by the Duncan's multiple range comparisons test with a significance level of $\mathrm{p}<0.05$.

\section{RESULTS AND DISCUSSION}

\section{Effect of fertilizer treatments on growth characteristics of oregano}

\section{Plant height and stem/ leaf/ flower dry weight}

The results of analysis of variance showed that the interaction of fertilizers application and year was significant on stem/ leaf/ flower dry weight, plant height and biological yield at $1 \%$ probability level (Table 2). Plant growth parameters (stem/ leaf/ flower dry weight, plant height and biological yield), in general, significantly improved with alone and combinations of chemical, organic and biological treated plots compared to control (non-fertilized) (Table 2).

According to the results of mean comparisons, maximum plant height $(99.50 \mathrm{~cm})$ was obtained from Nitroxin treatment in the second year followed by NPK + Nitroxin $(96.83 \mathrm{~cm})$ and NPK $(95.5 \mathrm{~cm})$ compared to Control (non-fertilizer), also there were no significant differences between them (Figure 1).

Stem/ leaf/ flower dry weight of oregano were significantly increased with Nitroxin as alone over Control (non-fertilized). According to the results of mean comparisons, the highest stem dry weight was related to Nitroxin (153.35 g/plant) followed by Nitroxin + bio super phosphate (145.13 g/plant) in the second year and the lowest one was obtained from Control (16.86 g/plant) in the first year, also there were no significant differences between Nitroxin and Nitroxin + bio super phosphate in case of stem dry weight (Figure 2).

The use of bio-fertilizers increased the leaf dry weight. Therefore the highest leaf dry weight was achieved from Nitroxin $(63.51 \mathrm{~g} /$ plant) followed by Nitroxin + bio super phosphate (61.61 g/plant) and NPK (60.62 g/plant) in the second year, which was not significantly different between them (Figure 3).

The results of analysis of variance on flower dry weight showed that the interaction of fertilizer application and year was significant. Based on the results of the mean comparison, the highest amount of flower dry weight was observed in Nitroxin treatment (85.92 g/plant) (Figure 4). 
Table 2. Effect of year and fertilizer treatments on stem, leaf and flower dry weight, plant height and biological yield in oregano.

\begin{tabular}{|c|c|c|c|c|c|}
\hline Treatments & $\begin{array}{c}\text { Stem dry weight } \\
\text { (g) }\end{array}$ & $\begin{array}{c}\text { Leaf dry weight } \\
(\mathrm{g})\end{array}$ & $\begin{array}{c}\text { Flower dry weight } \\
\text { (g) }\end{array}$ & $\begin{array}{c}\text { Plant height } \\
(\mathrm{cm})\end{array}$ & $\begin{array}{c}\text { Biological yield (kg } \\
\mathrm{ha}^{-1} \text { ) }\end{array}$ \\
\hline \multicolumn{6}{|l|}{ Year } \\
\hline $\mathrm{Y}_{1}$ & $40.50 \mathrm{~b}$ & $6.79 b$ & $7.01 \mathrm{~b}$ & $8.71 b$ & $2644 b$ \\
\hline $\mathrm{Y}_{2}$ & $83.27 \mathrm{a}$ & $102.70 \mathrm{a}$ & $44.64 \mathrm{a}$ & $57.47 \mathrm{a}$ & $20482 a$ \\
\hline \multicolumn{6}{|l|}{ Fertilizers } \\
\hline $\mathrm{C}$ & $11.92 \mathrm{~h}$ & $9.77 \mathrm{~h}$ & $8.64 \mathrm{i}$ & $45.20 \mathrm{i}$ & $3454 f$ \\
\hline $\mathrm{F}$ & $87.81 \mathrm{a}$ & $35.06 \mathrm{ab}$ & $47.88 \mathrm{ab}$ & 71.49ab & $17200 \mathrm{a}$ \\
\hline V & $38.49 \mathrm{fg}$ & $18.51 \mathrm{fg}$ & $24.90 f g h$ & 59.58fgh & $8167 \mathrm{e}$ \\
\hline B & $33.17 \mathrm{~g}$ & $16.44 \mathrm{gh}$ & 18.500hi & $57.24 \mathrm{~h}$ & $7114 \mathrm{e}$ \\
\hline $\mathrm{N}$ & $90.14 \mathrm{a}$ & $37.37 \mathrm{a}$ & $58.06 \mathrm{a}$ & $68.81 \mathrm{abc}$ & $18569 a$ \\
\hline $\mathrm{Ph}$ & $50.59 \mathrm{cdef}$ & $24.87 \mathrm{cdef}$ & 34.28defg & $58.23 \mathrm{gh}$ & $11234 \mathrm{~cd}$ \\
\hline $\mathrm{F}+\mathrm{V}$ & $60.20 \mathrm{bc}$ & $32.35 \mathrm{abc}$ & $34.79 \mathrm{def}$ & $67.27 \mathrm{bcd}$ & $12699 b c$ \\
\hline $\mathrm{F}+\mathrm{B}$ & $61.22 \mathrm{bc}$ & 30.86abcd & $30.15 \mathrm{efgh}$ & $61.88 \mathrm{efg}$ & $12509 b c$ \\
\hline $\mathrm{F}+\mathrm{N}$ & $63.90 b c$ & $27.83 \mathrm{bcde}$ & $38.09 \mathrm{bcde}$ & $71.77 \mathrm{a}$ & $13603 b c$ \\
\hline $\mathrm{F}+\mathrm{Ph}$ & $60.06 b c$ & $27.68 \mathrm{bcde}$ & $47.59 \mathrm{abc}$ & $59.12 \mathrm{fgh}$ & $13617 b c$ \\
\hline $\mathrm{V}+\mathrm{B}$ & $40.53 \mathrm{efg}$ & $20.60 \mathrm{efg}$ & $22.71 \mathrm{gh}$ & $57.74 \mathrm{gh}$ & $8695 \mathrm{de}$ \\
\hline $\mathrm{V}+\mathrm{N}$ & $53.12 \mathrm{cdef}$ & $24.59 \mathrm{cdef}$ & $29.45 \mathrm{efgh}$ & 63.06def & $10943 \mathrm{~cd}$ \\
\hline $\mathrm{V}+\mathrm{Ph}$ & $54.10 \mathrm{cde}$ & $23.75 \mathrm{defg}$ & 30.20efgh & $59.59 f g h$ & $11060 \mathrm{~cd}$ \\
\hline $\mathrm{B}+\mathrm{N}$ & $56.93 \mathrm{bcd}$ & 24.03defg & $36.49 \mathrm{cdef}$ & $64.90 \mathrm{cde}$ & $12189 b c$ \\
\hline $\mathrm{B}+\mathrm{Ph}$ & 42.78defg & 22.93defg & $25.75 \mathrm{fgh}$ & $56.27 \mathrm{~h}$ & 9259de \\
\hline $\mathrm{N}+\mathrm{Ph}$ & $70.93 b$ & $36.54 \mathrm{a}$ & 41.94bcd & $67.96 \mathrm{abc}$ & $14696 b$ \\
\hline \multicolumn{6}{|l|}{ Anova } \\
\hline $\mathrm{Y}$ & $* *$ & $* *$ & $*$ & $* *$ & $* *$ \\
\hline $\mathrm{T}$ & $* *$ & $* *$ & $* *$ & $* *$ & $* *$ \\
\hline $\mathrm{Y} * \mathrm{~T}$ & $* *$ & $* *$ & $* *$ & $* *$ & $* *$ \\
\hline
\end{tabular}

$\mathrm{Y}=$ year, $\mathrm{T}=$ treatment

$\mathrm{C}=$ control $, \mathrm{F}=\mathrm{NPK}, \mathrm{V}=$ vermicompost, $\mathrm{B}=$ biochar, $\mathrm{N}=$ nitroxin, $\mathrm{Ph}=$ bio super phosphate

Within a column, means with the same letter are not significantly different by Duncan's multiple range test $(p<0.05)$.

NS: no significant. *: Significant at the 0.05 level of probability. **: Significant at the 0.01 level of probability.

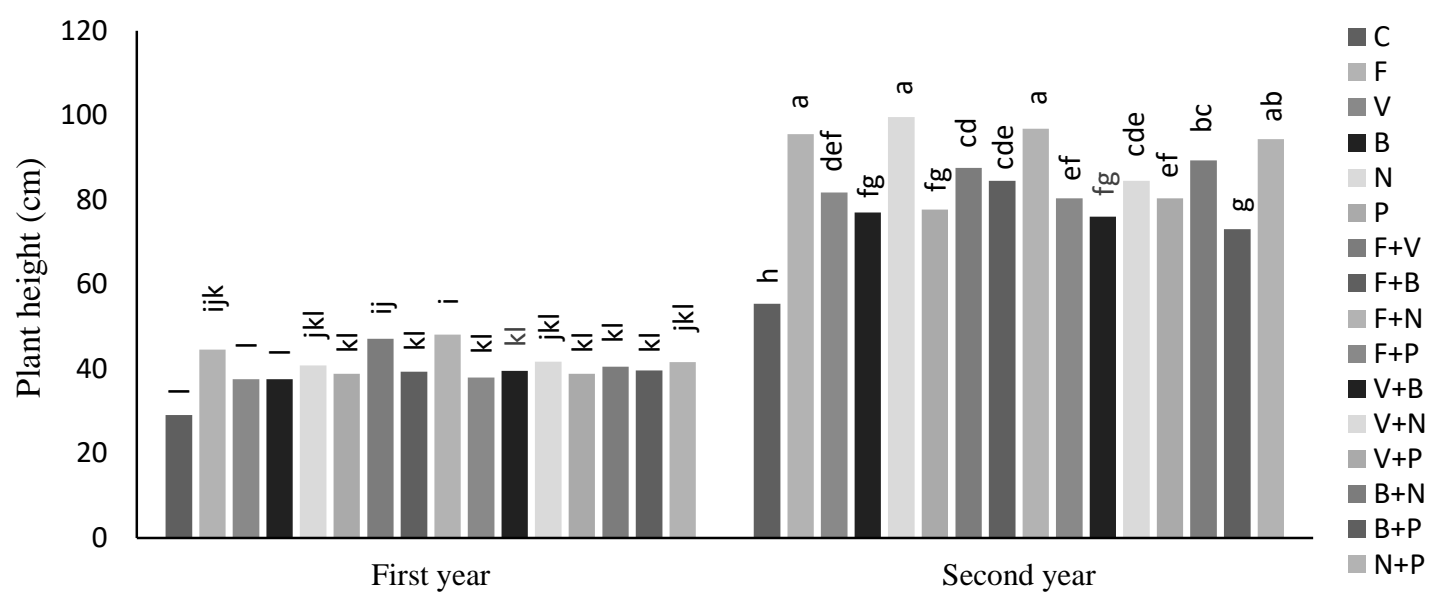

Figure 1. Interaction of fertilizers and year on plant height in oregano

$\mathrm{C}=$ control $, \mathrm{F}=\mathrm{NPK}, \mathrm{V}=$ vermicompost, $\mathrm{B}=$ biochar, $\mathrm{N}=$ nitroxin, $\mathrm{P}=$ bio super phosphate

Within a column, means with the same letter are not significantly different by Duncan's multiple range test $(p<0.05)$. 


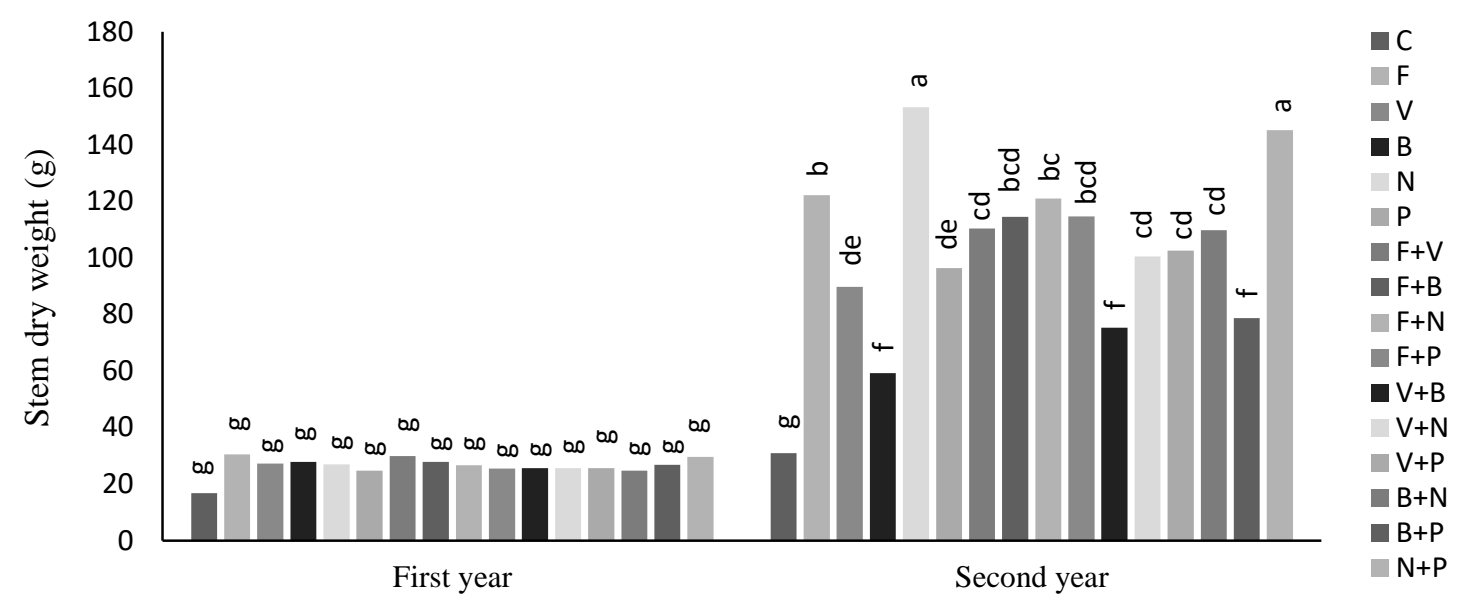

Figure 2. Interaction of fertilizers and year on stem dry weight in oregano

$\mathrm{C}=$ control $, \mathrm{F}=\mathrm{NPK}, \mathrm{V}=$ vermicompost, $\mathrm{B}=$ biochar, $\mathrm{N}=$ nitroxin, $\mathrm{P}=$ bio super phosphate

Within a column, means with the same letter are not significantly different by Duncan's multiple range test $(p<0.05)$.

In the first year of experiment, Oregano's growth was low because of oregano is perennial plants and the application of chemical fertilizer increased its growth. But in the second year, due to the development of roots and by increasing the activity of Azotobacter, Azospirillum and Pseudomonas and the transfer of atmospheric nitrogen to the plant through bacterial nitrogen fixation and the high growth-promoting substances produced by rhizobacteria, enhance root development, growth, and dry matter, also subsequently increased the nutrient uptake by the Oregano plants. For this reason, Oregano yield using Nitroxin biological fertilizer was more than chemical fertilizer in the second year.

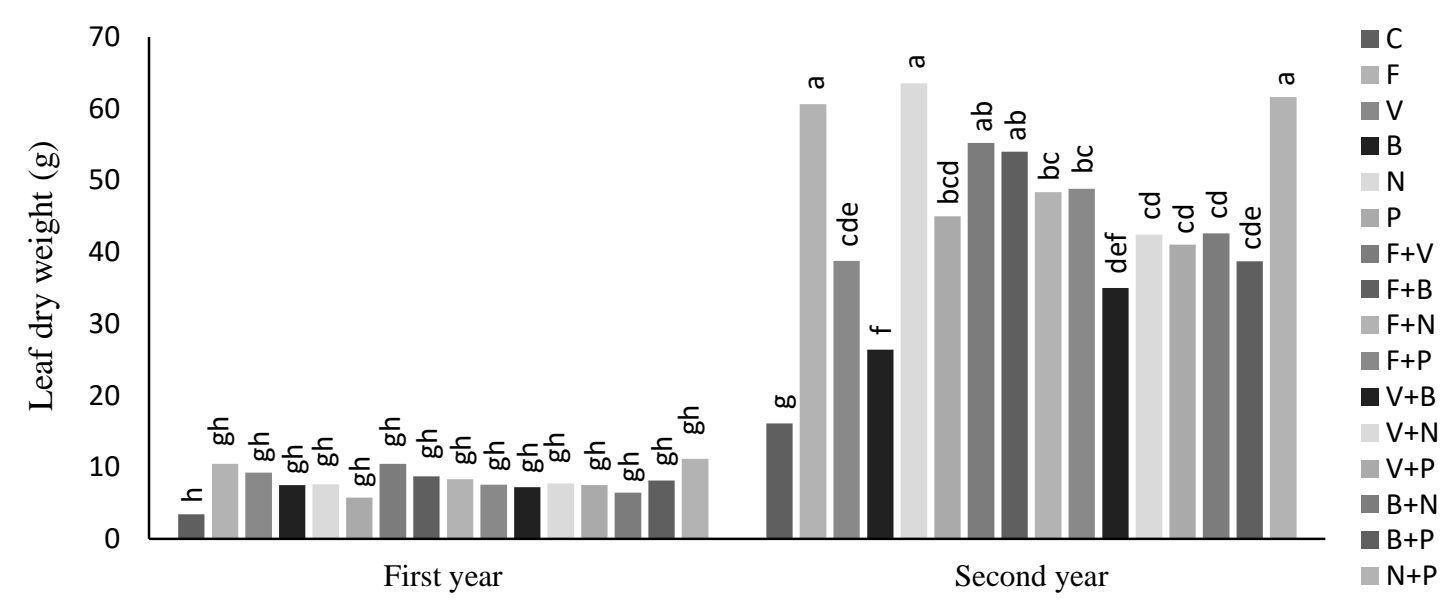

Figure 3. Interaction of fertilizers and year on leaf dry weight in oregano

$\mathrm{C}=$ control $, \mathrm{F}=\mathrm{NPK}, \mathrm{V}=$ vermicompost, $\mathrm{B}=$ biochar, $\mathrm{N}=$ nitroxin, $\mathrm{P}=$ bio super phosphate

Within a column, means with the same letter are not significantly different by Duncan's multiple range test $(p<0.05)$. 


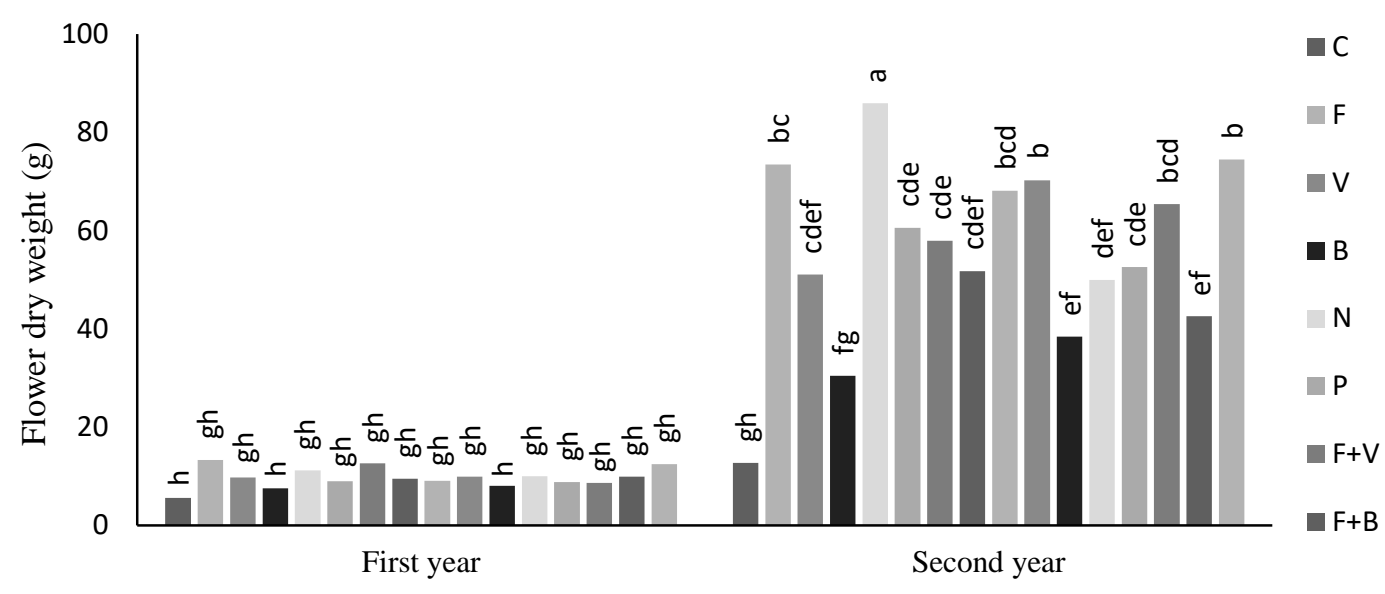

Figure 4. Interaction of fertilizers and year on flower dry weight in oregano

$\mathrm{C}=$ control $, \mathrm{F}=\mathrm{NPK}, \mathrm{V}=$ vermicompost, $\mathrm{B}=$ biochar, $\mathrm{N}=$ nitroxin, $\mathrm{P}=$ bio super phosphate

Within a column, means with the same letter are not significantly different by Duncan's multiple range test $(p<0.05)$.

Based on the results, the use of organic fertilizers improve the growth rate in plant due to better availability of water and nutrient uptake that causes growth improvement (Arancon et al., 2004). The ability of Azotobacter in increasing the solubility of phosphorus from inorganic insoluble compounds has been proven as one of the methods for increasing the mobility and absorption of nutrients. Therefore, Azotobacter can produce a proper rate between nitrogen and phosphorus by producing appropriate hormones or reducing ethylene. It can increase root and plant growth (Copetta et al., 2006). The results showed that use of bio-fertilizer (Azospirillum and Azotobacter) in Salvia (Salvia officinalis L.) increased the plant height and fresh and dry weight of the plant's aerial parts during the two seasons (Youssef et al., 2004) that our results are in agreement with this study. Similar observations were also obtained by Vittal Navi et al. (2006) in Basil, by Sing et al. (2012) in Patchouli and Coleus, by Valadabadi and Farahani (2011) in Nigella sativa, by Al-Fraihat et al. (2011) in Majorana hortensis and by Yadegari et al. (2012) on Thymus vulgaris.

Also in a study on oregano has shown that biofertilizers containing Azotobacter and Azospirillium can be replaced with nitrogen fertilizer in the cultivation of this plant and while reducing the production costs of fertilizer, it also prevents environmental damage (Fatma et al., 2006).

\section{Biological yield}

Biological yield significantly influenced by interaction of fertilizers and year at $1 \%$ probability level (Table 2). Based on the results of the mean comparison, the biological yield of oregano was significantly enhanced with alone and in combinations of fertilizers over control, but the highest yield was achieved with Nitroxin (30279 $\mathrm{kg} \mathrm{ha}^{-1}$ ) followed by Nitroxin + bio super phosphate $\left(28221 \mathrm{~kg} \mathrm{ha}^{-1}\right)$ in the second year compared to Control (non-fertilizer) (Figure 5). Also there were no significant differences between them.

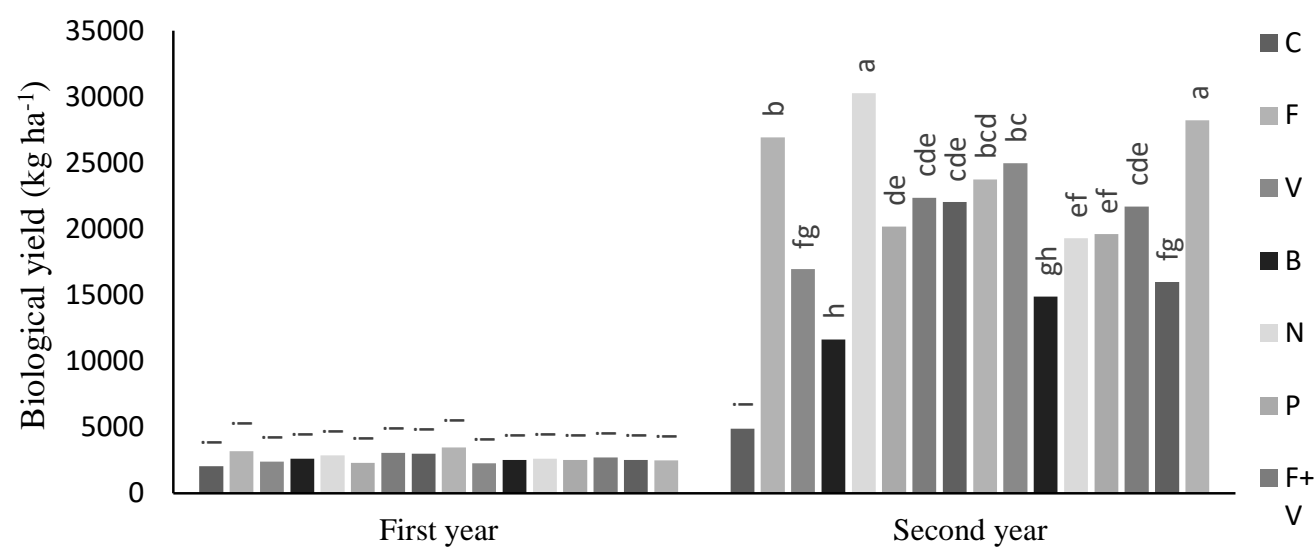

Figure 5. Interaction of fertilizers and year on biological yield in oregano

$\mathrm{C}=$ control $, \mathrm{F}=\mathrm{NPK}, \mathrm{V}=$ vermicompost, $\mathrm{B}=$ biochar, $\mathrm{N}=$ nitroxin, $\mathrm{P}=$ bio super phosphate

Within a column, means with the same letter are not significantly different by Duncan's multiple range test $(p<0.05)$. 
Plant growth-promoting rhizobacteria (PGPR) have the ability to increase seedling emergence, growth, vigour, establishment and therefore yield of various cereals and non-cereals crops (Grichko and Glick, 2001; Gravel et al., 2007) by enhancing the availability of phosphorous (Villegas and Fortin, 2002) and nitrogen (Anjum et al., 2007) to agricultural crops. Moreover, Azospirillum, in addition to nitrogen fixation, has improved root growth by increasing the production of growth stimulants, subsequently increasing the rate of absorption of water and nutrients and thus increase the yield (Tilak et al., 2005).

In an experiment that was conducted on the application of organic fertilizers in peppermint, the results showed that plant yield in organic farming was about $80 \%$ higher than conventional farming (Karla, 2003).

Azzaz et al. (2009) also reported that the application of biological fertilizers increased vegetative growth, yield and essential oil content in Fennel herb. In that case, our results are consistent with this research.

\section{Effect of fertilizer treatments on essential oil content and yield of oregano}

Results of analysis of variance showed that the interaction of fertilizers application and year on percentage and yield of essential oil was significant at $1 \%$ level of probability (Table 3). Mean Comparison showed that an increase of $76.50 \%$ in essential oil content observed in treatment with Nitroxin + bio super phosphate in the second year over Control (Figure 6). As a consequence of higher herbage yield, the essential oil yield was significantly increased by all the treatments as compared to control but the maximum oil yield was achieved in treatment with Nitroxin $(851.16 \%)$ (Figure 7).

Integrated application of Plant growth promoter bacteria contain nitrogen fixing bacteria and phosphate solubilizing bacteria through the improvement of essential oil yield components such as herb dry yield and essential oil content caused more essential oil yield. The useful effect of organic fertilizers levels on essential oil percentage may be due to the influence of organic fertilizers on accelerating metabolism reaction as well as stimulating enzymatic systems response for biosynthesis of essential oil content (Khalid and Hossein, 2012). Based on our results, oregano was not showed highly responsive to different organic and biological fertilizers in case of percentage of essential oil, but organic and biological fertilizers had more significant effect on essential oil yield in the second year, because of oregano is perennial plants, so second year's yield must be higher than that of first year. It has been reported that fennel essential oil yield increased by different organic fertilizers (Kapoor et al., 2004) that our results are in agreement with those reported on fennel.

Table 3. Effect of year and fertilizer treatments on essential oil content and yield, percentage of nitrogen, phosphorus and potassium of leaves in oregano.

\begin{tabular}{|c|c|c|c|c|c|}
\hline Treatments & Essential Oil Content (\%) & $\begin{array}{c}\text { Oil Yield } \\
\left(\mathrm{kg} \mathrm{ha}^{-1}\right)\end{array}$ & $\begin{array}{c}\text { Nitrogen } \\
(\%)\end{array}$ & Phosphorus (\%) & $\begin{array}{c}\text { Potassium } \\
(\%)\end{array}$ \\
\hline \multicolumn{6}{|l|}{ Year } \\
\hline $\mathrm{Y}_{1}$ & $1.56 \mathrm{~b}$ & $41.62 b$ & $2.43 b$ & $0.19 \mathrm{a}$ & $1.56 \mathrm{~b}$ \\
\hline $\mathrm{Y}_{2}$ & $2.40 \mathrm{a}$ & $507.49 \mathrm{a}$ & $2.53 \mathrm{a}$ & $0.13 b$ & $1.64 \mathrm{a}$ \\
\hline \multicolumn{6}{|l|}{ Fertilizers } \\
\hline $\mathrm{C}$ & $1.44 \mathrm{~h}$ & $53.26 \mathrm{i}$ & $0.88 \mathrm{~h}$ & $0.08 \mathrm{i}$ & $1.12 \mathrm{j}$ \\
\hline $\mathrm{F}$ & $2.03 \mathrm{cde}$ & $410.60 \mathrm{ab}$ & $2.66 \mathrm{bcd}$ & $0.24 \mathrm{bc}$ & $1.91 \mathrm{~b}$ \\
\hline V & $1.83 \mathrm{fg}$ & $163.71 \mathrm{~h}$ & $2.10 \mathrm{fg}$ & 0.13 fgh & $1.58 \mathrm{ef}$ \\
\hline B & $1.80 \mathrm{fg}$ & $149.82 \mathrm{~h}$ & $2.85 \mathrm{bc}$ & $0.14 \mathrm{fg}$ & $1.52 \mathrm{fg}$ \\
\hline $\mathrm{N}$ & $2.09 \mathrm{bcd}$ & $468.25 \mathrm{a}$ & $3.50 \mathrm{a}$ & $0.12 \mathrm{fgh}$ & $1.26 \mathrm{i}$ \\
\hline $\mathrm{Ph}$ & $2.03 \mathrm{cde}$ & 274.16def & $1.12 \mathrm{~h}$ & $0.27 \mathrm{a}$ & $1.39 \mathrm{~h}$ \\
\hline $\mathrm{F}+\mathrm{V}$ & $2.09 \mathrm{bcd}$ & $301.85 \mathrm{cde}$ & $3.47 \mathrm{a}$ & $0.17 \mathrm{e}$ & $1.76 \mathrm{c}$ \\
\hline $\mathrm{F}+\mathrm{B}$ & $1.99 \mathrm{de}$ & 288.23 cde & $2.45 \mathrm{def}$ & $0.14 \mathrm{f}$ & $1.65 \mathrm{de}$ \\
\hline $\mathrm{F}+\mathrm{N}$ & $2.18 \mathrm{abc}$ & $328.40 \mathrm{~cd}$ & $2.94 \mathrm{~b}$ & 0.13 fgh & $1.96 \mathrm{~b}$ \\
\hline $\mathrm{F}+\mathrm{Ph}$ & $2.10 \mathrm{bcd}$ & $347.69 b c$ & 2.36defg & $0.25 \mathrm{ab}$ & $1.70 \mathrm{~cd}$ \\
\hline $\mathrm{V}+\mathrm{B}$ & $2.09 \mathrm{bcd}$ & $213.08 \mathrm{fgh}$ & $2.06 \mathrm{~g}$ & $0.12 \mathrm{~h}$ & $1.57 \mathrm{ef}$ \\
\hline $\mathrm{V}+\mathrm{N}$ & $2.22 \mathrm{ab}$ & $280.36 \mathrm{cdef}$ & $2.96 \mathrm{~b}$ & $0.11 \mathrm{~h}$ & $1.47 \mathrm{fgh}$ \\
\hline $\mathrm{V}+\mathrm{Ph}$ & $1.90 \mathrm{ef}$ & 246.99efg & $2.26 \mathrm{efg}$ & $0.23 c$ & $1.50 \mathrm{fg}$ \\
\hline $\mathrm{B}+\mathrm{N}$ & $1.90 \mathrm{ef}$ & 267.24def & $2.58 \mathrm{cde}$ & $0.12 \mathrm{gh}$ & $1.44 \mathrm{gh}$ \\
\hline $\mathrm{B}+\mathrm{Ph}$ & $1.73 \mathrm{~g}$ & $183.18 \mathrm{gh}$ & $2.48 \mathrm{de}$ & $0.17 \mathrm{e}$ & $1.40 \mathrm{~h}$ \\
\hline $\mathrm{N}+\mathrm{Ph}$ & $2.26 \mathrm{a}$ & $416.05 \mathrm{a}$ & $3.01 \mathrm{~b}$ & $0.19 \mathrm{~d}$ & $2.37 \mathrm{a}$ \\
\hline \multicolumn{6}{|l|}{ Anova } \\
\hline $\mathrm{Y}$ & $* *$ & $* *$ & $* *$ & $* *$ & $* *$ \\
\hline $\mathrm{T}$ & $* *$ & $* *$ & $* *$ & $* *$ & $* *$ \\
\hline $\mathrm{Y} * \mathrm{~T}$ & $* *$ & $* *$ & NS & $* *$ & NS \\
\hline
\end{tabular}

$\mathrm{Y}=$ year, $\mathrm{T}=$ treatment

$\mathrm{C}=$ control $, \mathrm{F}=\mathrm{NPK}, \mathrm{V}=$ vermicompost, $\mathrm{B}=$ biochar, $\mathrm{N}=$ nitroxin, $\mathrm{Ph}=$ bio super phosphate

Within a column, means with the same letter are not significantly different by Duncan's multiple range test $(p<0.05)$.

NS: no significant. *: Significant at the 0.05 level of probability. $* *$ : Significant at the 0.01 level of probability. 


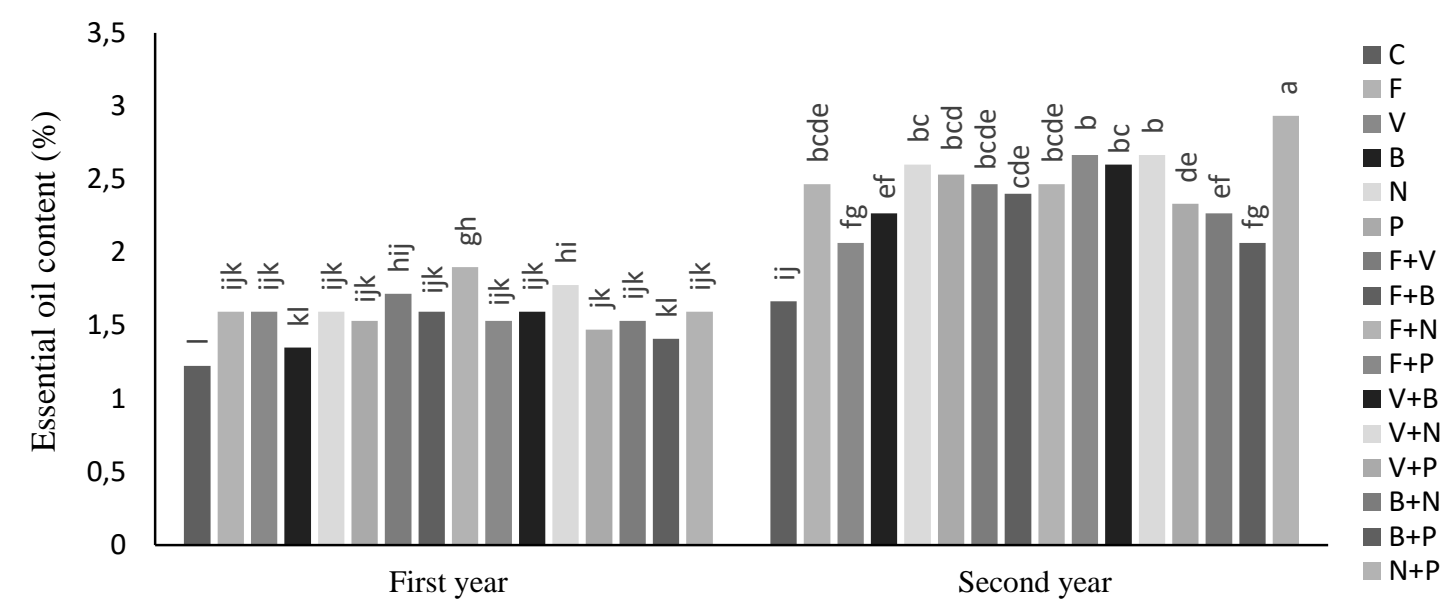

Figure 6. Interaction of fertilizers and year on essential oil content in oregano

$\mathrm{C}=$ control $, \mathrm{F}=\mathrm{NPK}, \mathrm{V}=$ vermicompost, $\mathrm{B}=$ biochar, $\mathrm{N}=$ nitroxin, $\mathrm{P}=$ bio super phosphate

Within a column, means with the same letter are not significantly different by Duncan's multiple range test $(p<0.05)$.

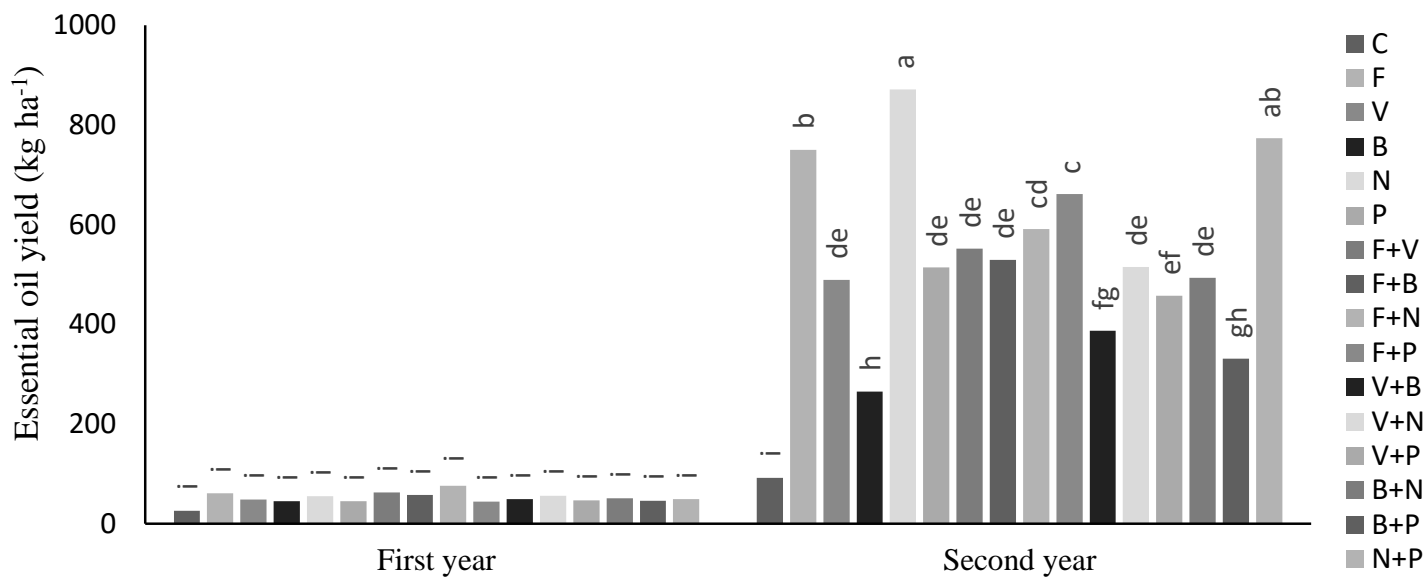

Figure 7. Interaction of fertilizers and year on essential oil yield in oregano

$\mathrm{C}=$ control $, \mathrm{F}=\mathrm{NPK}, \mathrm{V}=$ vermicompost, $\mathrm{B}=$ biochar, $\mathrm{N}=$ nitroxin, $\mathrm{P}=$ bio super phosphate

Within a column, means with the same letter are not significantly different by Duncan's multiple range test $(p<0.05)$.

Gharib et al. (2008) reported that inoculation of sweet marjoram (Majorana hortensis) plants with each of Azospirillum brasilienses, Azotobacter chrococcum, Bacillus polymyxa and B. circulans increased the essential oil yield and percentage of these species. Essential oil yield of Origanum majorana L. also was significantly increased in biofertilizer treatments relative to noninoculated plants, without alteration of oil composition (Banchio et al., 2008).

Similar observations were recorded in another trial with medicinal plant such as (Richter et al., 2005) in Marjoram, Thyme and Caraway, (Al-Fraihat et al., 2011) in Majorana hortensis, (Moradi et al., 2011) in Sweet fennel, (Rebey et al., 2012) in Cumin, (Darzi et al., 2012) in Anethum graveolens, (Yadegari et al., 2012) in Thymus vulgaris, (Najatzadeh, 2014) in Basil, (Hassan and Ali, 2014) in Coriander and (Roshanpour et al., 2014) in Basil.

\section{Effect of fertilizer treatments on nutrient concentration of leaves in oregano}

\section{Percentage of nitrogen, phosphorus and potassium}

The results of analysis of variance on phosphorus content showed that the interaction of fertilizers application and year was significant at $1 \%$ level of probability. Although, interaction of treatments had no significant effects on nitrogen and potassium content (Table 3). An increase of (237.34 \%) in phosphorus content was observed in treatment with Bio super phosphate followed by Nitroxin + Bio super phosphate $(213.25 \%)$ compared with control (Figure 8). 


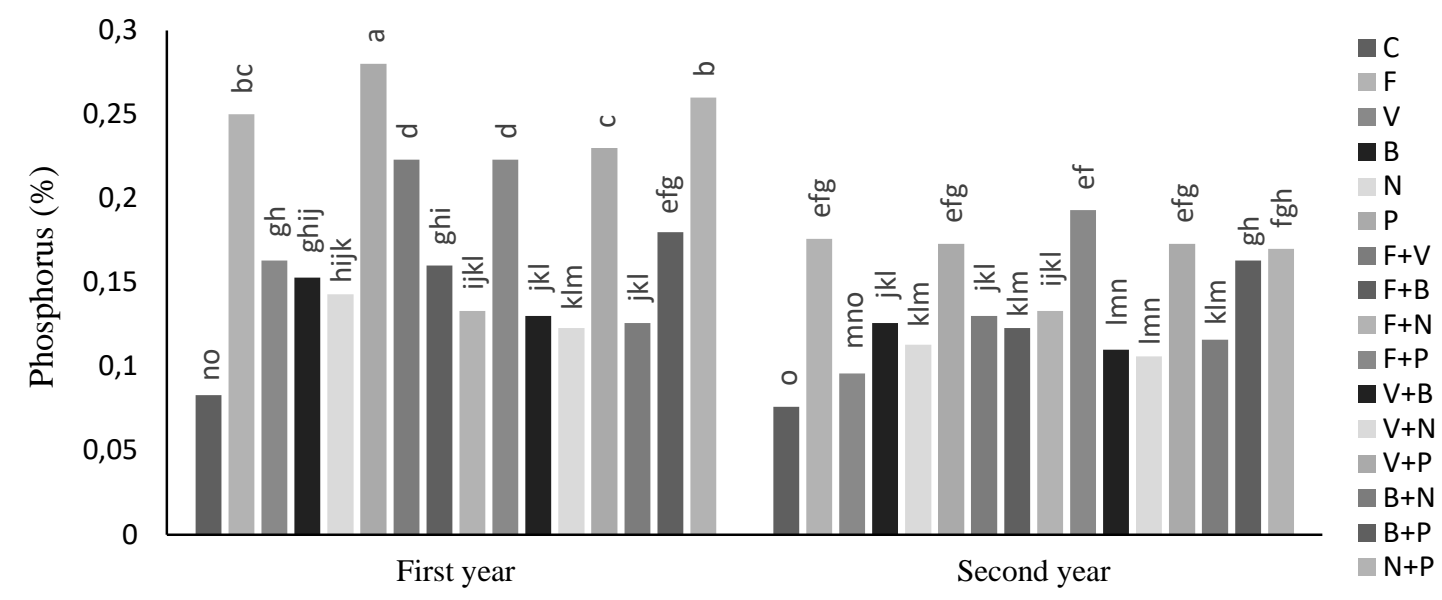

Figure 8. Interaction of fertilizers and year on phosphorus content in oregano

$\mathrm{C}=$ control $, \mathrm{F}=\mathrm{NPK}, \mathrm{V}=$ vermicompost, $\mathrm{B}=$ biochar, $\mathrm{N}=$ nitroxin, $\mathrm{P}=$ bio super phosphate

Whithin a column, means with the same letter are not significantly different by Duncan's multiple range test $(p<0.05)$.

The effect of fertilizers application and year on nitrogen and potassium was significant at $1 \%$ level of probability. Results of mean comparisons indicated that the effect of year and applying all of fertilizers increased the amounts of nitrogen and potassium.

Nitrogen content increased by $(297.72 \%)$ in Nitroxin over control. Similarly, application of NPK + Vermicompost increased the Nitrogen content by about (294.31\%) as compared to control though no significant difference was observed between them (Table 3). Similar results in the case of major nutrient content under integrated nutrient management were reported by (Anwar et al., 2005) in French basil. Potassium content significantly increased by $(111.60 \%)$ over control in Nitroxin + Bio super phosphate fertilizer compared with other treatments (Table 3). Also, mean comparison showed that the highest amount of nitrogen $(2.53 \%)$ and potassium $(1.64 \%)$ was obtained in the second year (Table 3).

It seems that the plant growth-promoting rhizobacteria (PGPR) have a positive effect on the amount of biomass production and photosynthesis through the high water absorption and the desirable availability of nutrients and improved nitrogen, phosphorus and potassium uptake in the plant. It also improves the physical conditions and vital processes of the soil, while creating an appropriate substrate for root growth, increases growth, accelerates metabolic reactions, increases the synthesis and accumulation of metabolites and ultimately improves the amount of essential oil. Also, organic fertilizers, including vermicompost, provide a desirable environment for replication of bacterial, as a result of these positive effects, it eventually increases nutrients absorption and plant growth (Zaller, 2007; Laboski and Lamb, 2003). The increase in nutrient uptake may be due to an increase in available $\mathrm{N}, \mathrm{P}$ and $\mathrm{K}$ contents in the soil, and improved soil structure for higher nutrients uptake (Manna et al., 2001).
Zaidi et al. (2003) reported that in low $\mathrm{P}$ soils, the highest plant growth and nutrient uptake in chickpea were obtained after inoculation with tripartite culture of Mesorhizobium, PSB, and G. fasciculatum. Our results are consistent with research of Ordookhani et al. (2010) who revealed that the combined application of PseudomonasAzotobacter-Azosprillum-AMF increased maximum potassium uptake by shoot and nutrient content as compared to the other treatments. Singh et al. (2012) found that Coleus forskohlii plants colonized by both Pseudomonas monteilii and Glomus fasciculatum had higher N, P, and $\mathrm{K}$ uptake and greater above-ground biomass. The application of dual inoculation with AM fungi and $\mathrm{N}$-fixing bacteria seems to be the most effective treatment combination to improve plant growth and plant nutrient uptake.

\section{CONCLUSION}

The present study clearly showed that the use of chemical fertilizer significantly improved the growth and essential oil yield of oregano in the first year. But in the second year, due to increase in fresh and dry yield of the oregano herb, a rising trend was observed in some traits because Oregano is perennial plant and by increasing the activity of Azotobacter, Azospirillum and Pseudomonas and the transfer of atmospheric nitrogen to the plant through bacterial nitrogen fixation, enhance root development, growth, and dry matter. Also sustain the health of soil that is the prime need for percent and future agriculture practices to maintain the health of the soil, economic and sustainable productivity of the agricultural system. Generally, the use of organic and biofertilizers or integration of them with inorganic fertilizers produced almost similar yield as compared to $100 \%$ chemical fertilizers. It is recommended to replace chemical fertilizers with bio-fertilizers to achieve sustainable agricultural goals. 


\section{LITERATURE CITED}

Al-Fraihat, A.H., S.Y.A. Al-dalain, Z.B. Al-Rawashdeh, M.S. Abu-Darwish and J.A. Al-Tabbal. 2011. Effect of organic and biofertilizers on growth, herb yield and volatile oil of Marjoram plant grown in Ajloun region, Jordan. Medicinal Plants Research 5(13): 2822-2833.

Aligianis, N., E. Kalpoutzakis, S. Mitaku and I.B. Chinou. 2001. Composition and antimicrobial activity of the essential oil from Origanum species. Agricultural and Food Chemistry 49(9): 4168-4170.

Anjum, M., M. Sajjad, N. Akhtar, M. Quereshi, A. Iqbal, A. Jami and M. Hassan. 2007. Response of Cotton to plant growth promoting rhizobacteria (PGPR) inoculation under different levels of nitrogen. Agricultural Research 45: 135143.

Anwar, M., D.D. Patra, S. Chand, A. Kumar, A.A. Naqvi and S.P.S. Khanuja. 2005. Effect of organic manure and inorganic fertilizers on growth, herb, oil yield, nutrient accumulation and oil quality of French basil (Ocimum basilcum L.). Communications in Soil Science and Plant Analysis. 36: 1737-1746.

Arancon, N.Q., C.A. Edwards, P. Bierman, C. Welch and J.D. Metzger. 2004. Influences of vermicompost on field Strawberries: 1. Effects on growth and yields. Bioresource Technology 93: 145-153.

Atkinson, C.J., J.D. Fitzgerald and N.A. Hipps. 2010. Potential mechanisms for achieving agricultural benefits from biochar application to temperate soils: a review. Plant and Soil. 337(1): 1-18

Azzaz, N.A., E.A. Hassan and E.H. Hamad. 2009. The chemical constituent and vegetative and yielding characteristics of Fennel plants treated with organic and biofertilizer instead of mineral fertilizer. Australian Journal of Basic and Applied Sciences 3(2): 579-587.

Bajeli, J., S. Tripathi, A. Kumar and R.K. Upadhyay. 2016. Organic manures a convincing source for quality production of Japanese mint (Mentha arvensis L.). Industrial Crops and Products. 83: 603-606.

Banchio, E., P.C. Bogino, J. Zygadlo and W. Giordano. 2008. Plant growth promoting rhizobacteria improve growth and essential oil yield in (Origanum majorana L.). Biochemical Systematics and Ecology. 36(10): 766-771.

Clevenger, J.H. 1928. Apparatus for the determination of volatile oil. American Pharmaceutical Association. 17(4): 346-349.

Copetta, A., G. Lingua and G. Berta. 2006. Effects of three AM fungi on growth, distribution of glandular hairs, and essential oil production in Ocimum basilicum L. var. Genovese. Mycorrhiza. 16: 485-494.

Darzi, M.T., M.R. Haj-Seyed-Hadi and F. Rejali. 2012. Effects of the application of vermicompost and nitrogen fixing bacteria on quantity and quality of the essential oil in Dill (Anethum graveolens). Medicinal Plants Research 6(21): 3793-3799.

Ding Y., Y.X. Liu, W.X. Wu, D.Z. Shi, M. Yang and Z.K. Zhong. 2010. Evaluation of biochar effects on nitrogen retention and leaching in multi-layered soil columns. Water, Air, and Soil Pollution. 213(1): 47-55.

Fatma, E.M., I. El-Zamik, T. Tomader, H.I. El-Hadidy, L. Abd El-Fattah and H. Seham-Salem. 2006. Efficiency of biofertilizers, organic and in organic amendments application on growth and essential oil of Marjoram (Majorana hortensis L.) plants grown in sandy and calcareous. Agric. Microbiology Dept., Zagazig University and Soil Fertility and Microbiology Department. Desert Research Center. Cairo. Egypt, p. 212-264.
Gharib, F.A., L.A. Moussa and O.N. Massoud. 2008. Effect of compost and Bio-fertilizers on growth, yield and essential oil of sweet Marjoram (Majorana hortensis) plant. International Journal of Agriculture \& Biology 10(4): 381-387.

Gravel, V., H. Antoun and R. Tweddell. 2007. Growth stimulation and fruit yield of greenhouse tomato plants by inoculation with Pseudomonas putida or Trichoderma atroviride: Possible role of indole acetic acid (IAA). Soil Biology and Biochemistry 39: 1968-1977.

Grichko, V.P. and B.R. Glick. 2001. Amelioration of flooding stress by ACC deaminase-containing plant growthpromoting bacteria. Plant Physiology and Biochemistry. 39: 11-17.

GUENTHER, E. 1961. The essential oils. D. von Nostrand Company Press. NY.

Hassan, F.A.S. and E.F. Ali. 2014. Impact of different water regimes based on class-A pan on growth, yield and oil content of Coriandrum sativum L. plant. Journal of the Saudi Society of Agricultural Sciences 13(2): 155-161.

Kapoor, R., B. GIRI and K.G. Mukerji. 2004. Improved growth and essential oil yield and quality in Foeniculum vulgare Mill. on mycorrhizal inoculation supplemented with Pfertilizer. Bioresource Technology 93(3): 307-311.

Karla, A. 2003. Organic cultivation of medicinal and aromatic plants. A hope for sustainability and quality enhancement. Journal of Organic production of Medicinal, Aromatic and Dye-Yielding Plants (MADPs), FAO. 198 p.

Karthikeyan, B., C. Abdul Jaleel, G.M.A. Lakshmanan and M. Deiveekasundaram. 2008. Studies on rhizosphere microbial diversity of some commercially important medicinal plants. Colloids and Surfaces B: Biointerfaces. 62(1): 143-145.

Khalid, K.A. and M.S. Hussein. 2012. Effect of cattle and liquid manures on essential oil and antioxidant activities of celery (Apium graveolens L.) Fruits. Essential Oil Bearing Plants. 15: 97-107.

Kim, K.R., J.G. Kim, J.S. Park, M.S. Kim, G. Owens, G.H. Youn and J.S. Lee. 2012. Immobilizer-assisted management of metal-contaminated agricultural soils for safer food production. Environmental management 102: 88-95.

Laboski, C.A.M. and J.A. Lamb. 2003. Changes in soil test phosphorus concentration after application of manure or fertilizer. Soil Science Society of America Journal. 67(2): 544-554.

Lehmann, J. 2007. Bio-energy in the black. Frontiers in Ecology and the Environment 5: 381-387.

LEU, A. 2007. Organics and soil carbon: Increasing soil carbon, crop productivity and farm profitability. In Managing the Carbon Cycle, Katanning, Western Australia, Workshop, p. 19-26.

Manna, M.C., P.K. Ghosh, B.N. Ghosh and K.N. Singh. 2001. Comparative effectiveness of phosphate-enriched compost and single superphosphate on yield, uptake of nutrients and soil quality under soybean-wheat rotation. Agricultural Sciences 137: 45-54.

Marinari, S., G. Masciandaro, B. Ceccanti and S. Grego. 2000. Influence of organic and mineral fertilizers on soil biological and physical properties. Bioresource Technology 72(1): 917.

Maurya, B.R., V.S. Meena and O.P. Meena. 2014. Influence of Inceptisol and Alfisol's potassium solubilizing bacteria (KSB) isolates on release of $\mathrm{K}$ from Waste mica. Vegetos. 27(1): 181-187.

Mehnaz, S. and G. Lazarovits. 2006. Inoculation effects of Pseudomonas putida, Gluconacetobacter azotocaptans and Azospirillum lipoferum on Corn plant growth under greenhouse conditions. Microbial Ecology 51(3): 326-335. 
Melero, S., E. Madejon, J.F. Herencia and J.C. Ruiz. 2007. Biochemical properties of two different textured soils (loam and clay) after the addition of two different composts during conversion to organic farming. Spanish Journal of Agricultural Research 5(4): 593-604.

Meena, O.P., B.R. Maurya and V.S. Meena. 2013. Influence of $\mathrm{K}$-solubilizing bacteria on release of potassium from waste mica. Agriculture for Sustainable Development. 1(1): 53-56.

Meena, V.S., B.R. Maurya and I. Bahadur. 2014. Potassium solubilization by bacterial strain in Waste mica. Bangladesh Journal of Botany 43(2): 235-237.

Moradi, R., P. Rezvani-Moghaddam, M. Nasiri-Mahallati and A. Nezhadali. 2011. Effects of organic and biological fertilizers on fruit yield and essential oil of sweet fennel (Foeniculum vulgare var. dulce). Spanish Journal of Agricultural Research 9(2): 546-553.

Nejatzadeh-Barandozi, F. and B. Pourmaleknejad. 2014. Effect of Biological, Organic and Chemical Fertilizers on Vegetative Growth, Physiological Characteristics and Essential Oils of (Thymus vulgaris L.). Annual Research \& Review in Biology 4(11): 1847-1853.

Ordookhani, K., K. Khavazi, A. Moezzi and F. Rejali. 2010. Influence of PGPR and AMF on antioxidant activity, lycopene and potassium contents in tomato. African Journal of Agricultural Research 5(10): 1108-1116.

Olsen, S.R. and J.F. Sommers. 1982. Phosphorus. In: A.L. Page (ed.), Methods of soil Analysis. Agron. No. 9, part 2: Chemical and microbiological properties, 2nd ed. American Society and Agronomy Madison, WI, USA, p. 403-430.

Patra, D.D., M. Anwarm and S. Chand. 2000. Integrated nutrient management and waste recycling for restoring soil fertility and productivity in Japanes mint (Mentha arvensis) and Mustard (Brassica juncea) sequence in Uttar Pradesh India. Agriculture Ecosystem and Environment 80(3): 267-275.

Radušienė, J., L. Ivanauskas, V. Janulis and V. Jakštas. 2008. Composition and variability of phenolic compounds in Origanum vulgare from Lithuania. Journal of Biologija. 54(1): 45-49.

RAO, B.R. 2001. Biomass and essential oil yields of rainfed palmarosa (Cymbopogon martinii) (Roxb.) Wats. var. motia Burk. supplied with different levels of organic manure and fertilizer nitrogen in semi-arid tropical climate. Industrial Crops and Products. 14(3): 171-178.

Raut, J.S. and S.M. Karuppayil. 2014. A status review on the medicinal properties of essential oils. Industrial Crops and Products. 62: 250-264.

Rebey, I.B., I. Jabri-Karoui, I. Hamrouni-Sellami, S. Bourgou, F. Limam and B. Marzouk. 2012. Effect of drought on the biochemical composition and antioxidant activities of cumin (Cuminum cyminum L.) seeds. Industrial Crops and Products. 36: 238-245.

Richter, J., M. Stutzer and I. Schellenberg. 2005. Effects of mycorrhization on the essential oil content and composition of aroma components of Marjoram (Marjorana hortensis), Thyme (Thymus vulgaris L.) and Caraway (Carum carvi L.). $36^{\text {th }}$ International Symposium on Essential Oils, 4-7 September 2005; Budapest, Hungary.

Roshanpour, N., M.T. Darzi and M. Haj-seyed-hadi. 2014. Effects of plant growth promoter bacteria on biomass and yield of Basil (Ocimum basilicum L.). International Journal of Advanced Biological and Biomedical Research 2(6): 2077-2085.
Schroth, G. and F.L. Sinclair. 2003. Trees, crops, and soil fertility: concepts and research methods. CABI Publishing, Wallingford, $437 \mathrm{p}$.

Seilsepour, M., E. Baniani and M. Kianirad. 2002. Effect of phosphate solubilizing microorganism (PSM) in reducing the rate of phosphate fertilizers application to Cotton crop. Proc $15^{\text {th }}$ Int Meeting on Microbial Phosphate Solubilization, Salamanca University, 16-19 July 2002. Salamanca, Spain.

Sinha, J., C.K. Biswas, A. Ghosh and A. Saha. 2010. Efficacy of vermicompost against fertilizers on Cicer and Pisum and on population diversity of $\mathrm{N}_{2}$ fixing bacteria. Environmental Biology 31(3): 287-292.

Singh, R., S. Divya, A. Ashutosh and A. Karla. 2012. Technology for efficient and successful delivery of vermicompost colonized bioionculants in Pogostemon cabin (patchouli) Benth. World Journal of Microbiology and Biotechnology 28(1): 323-333.

Sturz, A.V. and B.R. Christie. 2003. Beneficial microbial allelopathies in the root zone. The management of soil quality and plant disease with rhizobacteria. Soil \& Tillage Research. 72(2): 107-123.

Tilak, K.V.B.R., N. Ranganayaki, K.K. Pal, R. De, A.K. Saxena, C. Shekhar-Nautiyal, S. Mittal, A.K. Tripathi and B.N. Johri. 2005. Diversity of plant growth and soil health supporting bacteria. Current Science 89(1): 136-150.

Valadabadi, S.A. and H.A. Farahani. 2011. Investigation of biofertilizers influence on quantity and quality characteristics in Nigella sativa L. Horticulture and Forestry. 3(3): 88-92.

Vessey, J.K. 2003. Plant growth promoting Rhizobacteria as biofertilizer. Plant and Soil 255: 571-586.

Villegas, J. and J.A. Fortin. 2002. Phosphorous solubilization and $\mathrm{pH}$ changes as a result of interactions between soil bacteria and arbuscular mycorrhizal fungi on a medium containing $\mathrm{NO}^{3-}$ as nitrogen source. Canadian Journal of Botany 80: 571-576.

Vittal-Navi, H., B.S. Shivakumar, C.K. Suresh and N. Earanna. 2006. Effect of Glomus fasciculatum and plant growth promoting rhizobacteria on growth and yield of Ocimum basilicum. Karnataka Journal of Agricultural Sciences 19(1): 17-20.

Yadegari, M., G.H.N. Farahani and Z. Mosadeghzad. 2012. Biofertilizers effects on quantitative and qualitative yield of Thyme (Thymus vulgaris). African Journal of Agricultural Research 7(34): 4716-4723.

Youssef, A.A., A.E. Edris and A.M. Gomaa. 2004. A comparative study between some plant growth regulators and certain growth hormones producing microorganisms on growth and essential oil composition of Salvia officinalis L. Plant Annual. Agricultural Science 49: 299-311.

Zaidi, A., M.S. Khan and M. Amil. 2003. Interactive effect of rhizotrophic microorganisms on yield and nutrient uptake of chickpea (Cicer arietinum L.). European Journal of Agronomy 19(1): 15-21.

Zaller, J.G. 2007. Vermicompost as a substitute for peat in potting media: Effects on germination, biomass allocation, yields and fruit quality of three tomato varieties. Scientia Horticulturae 112(2): 191-199. 